\title{
The Acquisition of L2 Modern Standard Arabic Stress Patterns by L1 Chinese Native Speakers
}

\author{
By \\ Dr. Mona Maamoun \\ Lecturer of Linguistics \\ Faculty of Arts, Alexanderia University
}

DOI: $10.21608 /$ jfpsu.2021.68248.1054 


\title{
The Acquisition of L2 Modern Standard Arabic Stress Patterns by L1 Chinese Native Speakers
}

\begin{abstract}
Chinese learners of Modern Standard Arabic (MSA) as a second language (L2) show many pronunciation difficulties that lead to unintelligible verbal communication with Egyptian native speakers. These difficulties are resulted from many variables, such as the differences between the phonological system of the learners' first language (L1) and the learned one. These pronunciation challenges can occur across segmental and supra-segmental levels. MSA is regarded as a non-tone language, while Chinese is a tone one. Hence, this study aims at describing the acquisition of MSA stress by L1 Chinese speakers. The participants of the current study are twenty Chinese students aged $20-22$. Each participant was asked to read thirty words that represent the MSA stress rules. The percentage of mean of the correct productions of stress positions by the participants was calculated. Results of the current study show that Chinese participants have the ability to place MSA stress in the right position.
\end{abstract}

Key words: MSA, Chinese, L1, L2, Pronunciation, Stress. 


\section{اكتساب الصينين لنبر اللغة العربية كلغة أجنبية}

\section{مستخلص البحث}

أظهرت الدراسات المعنية باكتساب اللغات الأجنبية أن الظواهر الفوقطعية يمكن أن

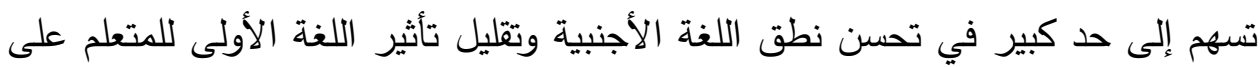

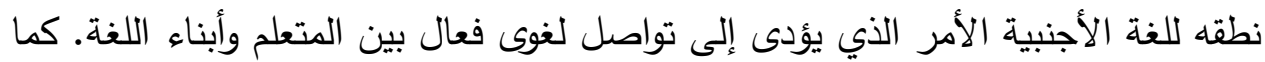

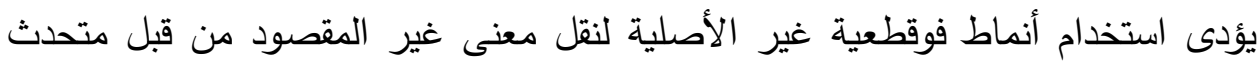

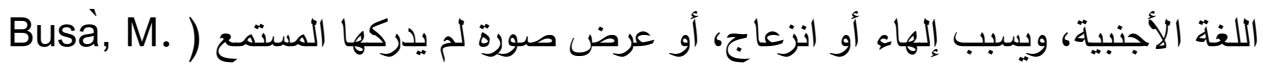

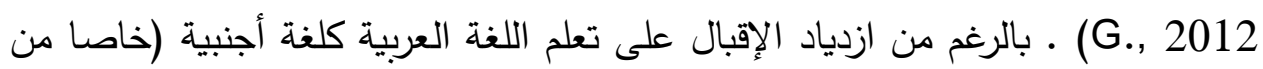
قبل الصينين) إلا أن دراسة اكتساب اللغة العربية كلغة أجنبية لا تحظى بالاهتمام الكبير الإدياد

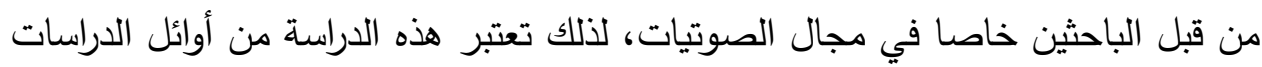
المرتمة بوصف اكتساب عنصر من عناصر النظام الفونولوجي للغة و وهو نبر اللغة العربية المعاصرة الحديثة. تشتمل العينة على عدد عشرين مشارك صيني من متعلمي

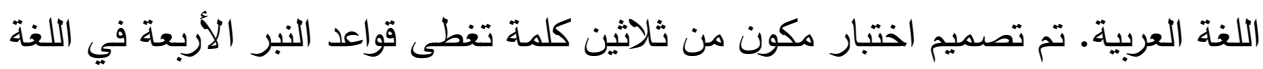
العربية وذلك لتقييم قدرة المشاركين على نطق و استخدام النبر في هذه الكلمات. وفقا

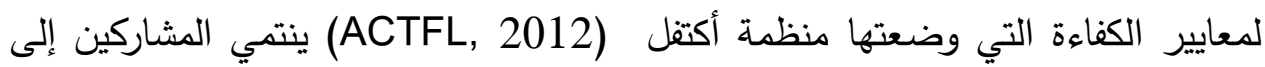
مستويين لغويين المستوى المتوسط والمستوى المتقدم. تم التحليل الفونولوجي و الإحصائي للعينة الكلامية للمشاركين وتم التوصل إلى العديد من النتائج على سبيل المثال وليس وليس الحصر وضوح قدرة المشاركين في الدراسة من الصينين على وضع النبر بصورة صحيحة على الكلمات العربية بنسبة تتعدى 90\%، و في حالة نطق بعض كلمات الاختبار بصورة

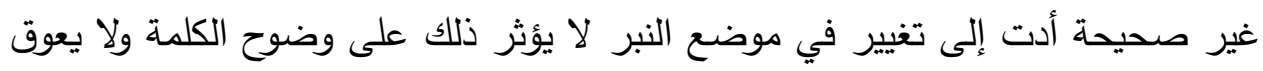
هذا التواصل اللفظي الواضح المفهوم بين الصينين وأبناء اللغة العربية.

الكلمات المفتاحية: الصينين، اللفة الأولى، النظق، النبر. 


\section{$\underline{\text { Introduction }}$}

Chinese learners of Modern Standard Arabic (MSA) as a foreign language show many pronunciation difficulties that may convey non-intended meaning and lead to distraction and miscommunication. These pronunciation challenges can occur across segmental and suprasegmental levels. To our knowledge, there are no previous studies concerned with describing the acquisition of MSA prosody by L1 Chinese speakers. As noted by Liang,L (2017)1 the rate of Chinese university students that are willing to learn Arabic increases. They regard Arabic as a chance for getting better career opportunities. Hence, more studies are needed to investigate and describe their linguistic needs and challenges for better ways of learning Arabic. The current study investigates the acquisition of L2 MSA stress as (L1) Chinese learners. By This study, we are trying to figure out whether it challengeable for L1 Chinese speakers to produce L2 MSA stress patterns.

\section{$\underline{\text { Stress }}$}

Stress is defined by Roch, p ( 1991) $)^{2}$ from two perspectives: production and perception. The articulatory production of stressed syllable involves more muscular energy than those required for the articulation of the unstressed syllables. Perceptually, stress syllables are prominent. Prominence is related to many variables such as pitch, loudness, and length (Liu, D., 20173; Chakraborty, R. et al., 20104; Al-Jarrah, R., 20025).

According to Fry $(1958)^{6}$, stress is the result of the interaction of pitch, intensity, and duration. A stressed syllable is often louder and longer than an unstressed syllable. Stress gives a certain basic prominence to the syllables, and hence to the words, on which it is used, and incidentally assists in avoiding monotony. 
Stress usually can be categorized into two types according to its context. When it occurs in a word linguistic environment (including compound or isolated words), it is called word stress. A sentence stress represents stress when it occurs across the sentence (including phrase) level and connected speech.

Primary stress is the most prominent syllable of the word. In languages that permit more than one position of stress, secondary stress is weaker than the primary stress, but at the same time it considered stronger than that of the unstressed syllable $(\mathrm{Ou}, \mathrm{S} ., \&$ Ota, M.,2015) ${ }^{7}$. Some languages that have fixed stress patterns, such as French and Finnish. Fixed stress pattern means that stress falls on one fixed syllable above every word and its position can be predicted based on the phonological features of the word. Languages such as these do not pose a challenge to cross-linguistic phonological investigations about word-stress behavior and their stress pattern can be easily acquired by foreign language learners (Al-Jarrah, R., 2002; Altmann, H., 2006 8 ; Liu, D., 2017 $)$. Meanwhile, there are some other languages such as Arabic and English that have not fixed stress patterns, they have stress rules that differ from phonological context to another (Al-Jarrah, R., 2002; Liu, D., 2017).

Prosody including stress is regarded as one of the most challenging areas of L2 acquisition, thus, difficulties of acquiring prosody persist and continue to be faced by learners of advanced levels (Özçelik, Ö., 2016 $)^{10}$.

Pronunciation errors in the speech of foreign language learners may be governed by many variables such as the phonetic and phonological feature differences between the learned language and the learner's first language. These differences unconsciously direct the learner to adapt his/her first language phonological features to pronounce L2 with their foreign accent. This transfer and adaptation occur as a procedure to overcome pronunciation difficulties they may face because their L1 lacks these phonological features. At the 
stress level, the transfer of L1 into L2 can be detected in the nonnative accent produced by the learners. L1 transfer isn't the only variable that influences second language pronunciation deviations. Otherwise, factors such as the learner's age may also lead to L2 prosodic deviations. (Selinker, 1972:11 Eckman, 1977, 1991, 2008 ${ }^{12}$; Hancin-Bhatt, 2008 ${ }^{13}$; Yang, C., 2011 ${ }^{14}$ ). Many studies such as He, X. et al. (2012) ${ }^{15}$, Johnson et al. (1989) ${ }^{16}$ noted that younger learners have the ability to acquire L2 at a higher and more near-native level than older learners. The ignorance of the importance and essentiality of the pronunciation class can be an added factor to the previous ones. Foreign language learners need a separate class that is devoted and designed to work on their phonetics and pronunciation skills. As noted by Jarrah (2012), phonological training should be part of the L2 learning process. Hence, introducing phonetics and phonology to L2 learners of Arabic at early stages leads to the acquisition of accurate pronunciation, and "intelligible speech is a basic requirement for communication competence" Morley $(1991)^{17}$. Pan, Q. (2012) ${ }^{18}$ admitted that during the journey of learning a foreign language, a mistake in intonation could has a negative impact on L2 language acquisition as the one done by a grammatical mistake. The prosody of an utterance plays a significant role in determining the meaning of the utterance and can't be neglected.

Spoken languages consist of grammatical forms, as well as prosodic functions that convey the emotional condition of the speaker (Tonhauser,J 2019) ${ }^{19}$.

\section{The Aim of the Study}

The current study is considered as a pioneer in this point of research. It describes the acquisition of L2 MSA stress by L1 Chinese speakers of different language proficiency levels. It also aims to examine the extent of L1 Chinese phonological system transfer into L2 MSA. 


\section{$\underline{\text { Research Questions }}$}

- What are the phonological patterns of acquiring L2 MSA stress by L1 Chinese speakers?

- Does the fact that the Chinese language is a tonal language influence the acquisition of L2 MSA stress?

- Does the stress placement of the L2 MSA target words by the L1 Chinese participants (whether it is correct or incorrect) influence these target words' pronunciations and vice versa?

Before representing the methodology of the current study, we must first go through a phonological review of the two languages' stress patterns. The coming review will illustrate how both languages resemble each other and how they are distinguished from each other across the stress features.

\section{The MSA Stress Phonology}

Although Arabic is a non-tone language, it regards as a stress-timed language (Al-Aloula, 2018) ${ }^{20}$. Thus, stress is fundamental in standard Arabic. Stress in Arabic is described as the degree of emphasis that is used in producing a certain syllable and it is perceived with more loudness/prominence in listeners' perception than the other syllables in the same word (Betti et al., 2018) ${ }^{21}$. MSA stress is non-phonemic (Al-Jarrah, R., 2002; Holes, C., 1995) ${ }^{22}$. Hence, stress cannot be used to distinguish meanings (Holes, C., 2004; Halpern, 200923; Ryding, K. C. $2005^{24}$ ). Alrajeh, N., (2011) ${ }^{25}$ noted that duration and intensity are the most consistent phonetic correlates of stress in MSA.

The internal structure of the Arabic syllables can be classified into three categories according to syllables' weights: light (CV), heavy (CV: - CVC), and super heavy, (CV:C - CVCC-CV:CC). See table (1) for the different types of MSA syllabic structure. 
Dr. Mona Maamoun

\begin{tabular}{|c|c|c|c|}
\hline The syllable & $\begin{array}{l}\text { Words } \\
\text { Represent the } \\
\text { Syllable in } \\
\text { Arabic }\end{array}$ & $\begin{array}{l}\text { Words } \\
\text { Represent the } \\
\text { Syllable } \\
\text { Transcribed }\end{array}$ & $\begin{array}{l}\text { Word } \\
\text { Syllabification }\end{array}$ \\
\hline $\mathrm{CV}$ & كتب & Kætæbæ & CV-CV-CV \\
\hline CVC & مكتب & Mæktæb & CVC-CVC \\
\hline CVV & كاتب & kæ:tib & CVV-CVC \\
\hline CVVC & مكتوب & mæktu:b & CVC-CVVC \\
\hline CVCC & كتب & kætb & CVCCC \\
\hline CVVCC & مار & maarr & CVVCC \\
\hline
\end{tabular}

\section{Table (1) the MSA Syllable Types}

Regarding these syllables' word distribution, it is noted that CV and CVC occur in all word positions, while CVV occurs initially or prefinally as in /kæ: tib/ (cvv-cvc) "كاتب", /dæ: Piman/ (cvv-cv-cv) "قاداتهم". "قائما", qa:. da.tu.hum (cvv -cv-cv-cvc) and CVVC as in / Saa.li.maan/ (cvv-cv-cvvc) " عالماً" and CVCC occur only finally.

There are some phonological constraints on the MSA phonotactics. For example, MSA syllable starts neither with a vowel nor with a cluster. The maximum number of clusters is two and it occurs only at the coda position. At the medial position, a sequence of two segments across syllable boundaries does occur. In MSA, it isn't allowed for all the types of segments to be clustered together. Stress distribution is positioned from the end of the word (Alrajeh, N., 2011; Halpern, 2009; Watson, 2011) ${ }^{26}$. If the rightmost syllable is super heavy as in (CV.'CV:C) for /ki.'ta:b/"كتاب"and (CV:.CV.'CV:C) for /ta:.li.'ba:t/ "طالبات", it will be stressed. On the other side, if there is no ultimate super heavy syllable in a word as in (CV.'CV:.CVC) for /ma.'ka:.nis/ "مكانس", heavy penultimate syllable is the one that will carry the stress. In the disyllabic word with no heavy syllables as ('CV.CVC) for /'wa.lad/ "ولد", stress falls on a penultimate syllable. Finally, if a heavy penultimate syllable doesn't exist, stress moves leftward to fall on the antepenultimate syllable, 
even though if it is either light or heavy like /'na.mi.ra/ (Alrajeh, N., 2011;27 Halpern, 2009; Ryding, K. C. 2005).

\section{The Chinese Stress Phonology}

Chinese is a tone language in which the meaning changes when the tone changes (Roach, 2003) ${ }^{28}$. In such a language, prominence is mainly achieved by variations in pitch level. Tone languages have contrasting pitches; the same string of segmental sounds will have different meanings when pronounced with different tones. This means that a language is considered as a tone one, when differences in pitch signal differences in lexical meanings.

Chinese has two different prosodic levels, lexical level (tones) prosody, and utterance level prosody (intonation). The fundamental frequency (F0) represents both lexical tones and intonation. In Chinese, the meaning of words can be distinguished by using either different (F0) or pitch patterns over a syllable in single words, or different F0 and intonation over an utterance (Xu, Y. 2015 ${ }^{29}$; Huang et al., 2014 ${ }^{30}$ ). The Chinese syllable contains four segments or less, allowing the combinations of consonants $(\mathrm{C})$, vowels $(\mathrm{V})$, and glides (G). The structure of the syllables of standard Chinese is (V, CV, $\mathrm{CVC}, \mathrm{CVG}, \mathrm{CGV}, \mathrm{CGVC}$, or $\mathrm{CGVG}$ ). The vowel is almost obligatory in all Chinese varieties. In Chinese, the long syllable is the most prominent and emphasized, and stress is used to emphasize the meaning of the word. However, the nature of the Chinese stress is controversial (Yastreblyanska, 2012) ${ }^{31}$. Linguists as Chao $(1965)^{32}$ and Duanmu (2007) ${ }^{33}$ noted that the Chinese language has stress patterns, others as Altmann, H. (2006) and Archibald, J. $(1997)^{34}$ showed a counter hypothesis in which the Chinese language has no stress rules. Duanmu, S (2007) argued that Chinese stress is not easy to perceive because Chinese supra-segmental features rely mostly on its lexical tones, at the same time, Chinese words are monosyllabic and don't have many poly-syllabic words. In dissyllabic words or compounds, the second syllable is louder in 
intensity and longer in duration (70\% of Chinese disyllabic words). Duanmu (2005) proposed that Mandarin Chinese has initial stress because of the alteration of strong and weak syllables. In Chinese, stress is primarily an enlargement in pitch range and time duration and secondarily in loudness (Chao, 1965 ${ }^{35}$; Aijun, L., 2002) ${ }^{36}$.

In Chinese, stress is not as significant as that in English due to the existence of tones that make stress in Chinese not essential. The features of pitch, intensity, and duration are the three factors that lead to the realization of stress in Chinese (Chao, 1968) ${ }^{37}$. Stress in the Chinese language is non-distinctive and correlates with a higher pitch and greater intensity and longer time length (Wei, 2003). In Chinese, it is the tone that contrasts the meaning of words (Zhao, 2006).

In Chinese, almost every word has only one syllable (Kelly, 2000), and each syllable has an inherent pitch contour. The minimal pairs (or larger minimal sets) exist between syllables with the same segmental features but different tones. Modern standard Chinese pronunciation has five linguistic tones: high level (Tone 1, -), rising (Tone 2, '), falling-rising (Tone 3, '), falling (Tone 4, '), and neutral tone. The neutral tone has no specific contour; its pitch depends on the tones of the preceding and following syllables. Chinese speakers refer to this tone as the 'light tone'. This tone occurs only on unstressed syllables. These five tones, when applied to the same sequence of sounds, represent different meanings. When a Chinese speaker pronounces the word "ma" with different tones as (mā, má, mă, mà, and ma) they will represent the following meanings respectively "mum", "hemp", "horse", "scold", and "an interrogative particle".

That is to say, the meaning of a Chinese word is detected by the pitch level of the syllable and its specified tone. Due to this reason, stress in Chinese does not play a major role in Chinese phonology as tone does. For example, the Chinese disyllabic word 葡萄 (grape) 
can be read with the first syllable stressed as /'putao/ or the second syllable stressed as /pu'tao/ without changing the meaning of the word. Therefore, we can see that compared with the tones, stress seems to be of less importance in discriminating lexical meaning in Chinese.

From this previous review, it is well illustrated that although the MSA phonology has stress rules and constraints while the Chinese doesn't, stress isn't distinctive in both languages.

\section{Previous Studies of the Acquisition of L2 MSA Stress $\underline{\text { Patterns }}$}

Al-Aloula (2018) investigated how native speakers of Standard American English (SAE) acquire lexical stress of L2 MSA. Both languages, SAE and MSA, use stress to signal prominence at the word level but also differ in prosodic patterning. The results indicated that duration was a significant cue of lexical stress for L2 speakers. SAE learners of L2 MSA produce a greater degree of duration contrast in their production of stressed and unstressed syllables to cue stress. Thus, the difference in the production of the L2 speakers due to the L1 prosodic transfer into MSA lexical stress cues. This transfer directs SAE speakers to use duration contrast while producing MSA stress.

\section{Methodology}

\section{$\underline{\text { Participants }}$}

The participants of the current study are twenty adult native speakers of Mandarin Chinese, aged $20-22$, and they belong to the southwestern region of China. Their dialect phonology has tones that are similar to those of Standard Chinese. They studied Arabic in a Chinese university for two years (twenty credit hours a week) in two semesters for eight months a year. Then they studied MSA for 
eight months (sixteen credit hours) weekly along two semesters at Alexandria University, Egypt. Meanwhile, they studied Egyptian Colloquial Arabic (ECA) for (two credit hours) weekly across two semesters. The participants had also exposed to the English language. As they had the opportunity to live in Egypt, they practiced speaking Arabic outside the class with Egyptian native speakers.

Concerning their language proficiency level, based on the ACTFL Oral Proficiency Interview (OPI) test (ACTFL, 2012), they were classified into two proficiency levels. Ten participants belong to the intermediate level and ten belong to the advanced level. They were interviewed and evaluated by a certified ACTFL tester.

\section{$\underline{\text { Speech Sample }}$}

A stress test of thirty words was designed to test the ability of Chinese learners of MSA to produce MSA stress patterns accurately. The target words were selected from "AL-Kitaab fii Tacallum alcArabiyya" (Brustad, K., Al-Batal, M., \& Al-Tonsi, A.,2007) ${ }^{38}$. The vocabulary of "AL-Kitaab fii Tacallum al-cArabiyya" are collected from three Arabic varieties: MSA, Egyptian colloquial Arabic and Levantine colloquial Arabic. Target words of the current study are chosen from MSA word list.

The target words are classified into four groups. Each group represents a MSA stress rule that determines syllable weight and position. Group one represents the first rule of stress that assigns stress to the super heavy syllable. Group two represents the second rule that assigns stress to the heavy penultimate syllable if there is no ultimate superheavy syllable. In group three, stress falls on a penultimate syllable in the disyllabic word that does not have final super heavy syllable. Group four assigns stress on the antepenultimate syllable if a heavy penultimate syllable doesn't exist. 
The test was composed of five columns. The first column is for the target words grouped according to the four stress rules. The second column is for the transcription and syllabification of the target words. The third is for transcription and syllabification of the participants' responses. The fourth for indicating whether the participants' responses correct or incorrect, and finally the fifth for identifying the phonological error processes and recording notes (see appendix I for stress word test).

\section{Elicitation and Recording Procedures}

The speech sample was elicited by reading the target words presented on the laptop screen. The researcher explained how the recording process would be going on and each participant was given some instructions to avoid eliciting an unreliable speech sample, as follows:

- Participants were informed to read stress word targets in a normal speech rate and without nunation and with sukuun (silence) at the final consonant.

The target words are common and easy to read without vowelization (short diacritic vowels) so they were not vowelled except word /ta. Zaw.wul/ because it can be also pronounced /ta.Za.wa.la/ if it has not vowelization. During sample eliciting, the researcher and a trained phonetician were making a live phonemic transcription for the participants' pronunciation and syllabification. Later, the recordings of participant were played back, and a transcription was done by another trained phonetician. Then the three transcribers compared their final transcribed results with each other following an intra-judge agreement strategy.

The sample of the study was recorded by using of The BOYA BYM1 microphone at a sampling rate of $65 \mathrm{~Hz}-18 \mathrm{kHz}$. 


\section{$\underline{\text { Analysis }}$}

The percentage of mean of the correct productions of participants in stress position in a target words related to each one of the four MSA stress rules was calculated to compare between the four MSA stress rules.

\section{$\underline{\text { Results }}$}

Results of the current study show that Chinese participants have the ability to place MSA stress in the right position. Advanced- level participants placed stress correctly on 280 targets out of 300 overall numbers of words along the 20 participants. Almost all participants placed stress much like native speakers except one participant who placed stress wrongly at five targets. (See figure 1) for the percentages of stress placement correct responses by intermediate level participants, and (figure 2) for the percentages of stress placement correct responses by advanced level participants

Across the whole Intermediate- level participants, it is noticed that $80 \%$ of the participants produce more than $95 \%$ of the target word stress placement in an accurate way. They stress correctly on 271 targets out of 300 . Seven out of ten students placed stress correctly at all the target words except word /wa(a):.'li.da.ti(i)/ just like all participants missed it. However, participant "L" placed stress wrongly on 13 words hence its score is the lowest. 


\section{Intermediate participants- Stress Placement}

\section{$120.00 \%$}

$100.00 \%$

$80.00 \%$

$96.60 \%$

$96.60 \%$

$93.30 \% 96.60 \% 96.60 \% 96.60 \% 96.60 \% 96.60 \%$

$60.00 \%$

$40.00 \%$

$20.00 \%$

$0.00 \%$

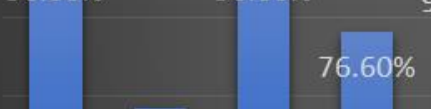

\section{$76.60 \%$}

\section{$56.60 \%$}

\section{Figure1}

\section{The Percentages of Stress Placement Correct Responses by}

\section{Intermediate Level Participants}

Across the whole participants, it is observed that $90 \%$ of the advanced- level participants placed stress correctly on more than $90 \%$ of the target words. Almost all participants placed stress much like native speakers except participant "A" placed stress wrongly at five targets. 


\section{Advanced Participants- Stress placement}

$100.00 \%$

$95.00 \%$ $96.60 \% 96.60 \%$ $96.60 \% 96.60 \%$ $96.60 \%$ $96.60 \%$

$90.00 \%$ $93.30 \%$

$85.00 \%$

$80.00 \% \quad 83.30 \%$

$75.00 \%$

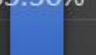

A

B

C

D

E

F

G

$\mathrm{H}$

\section{$\underline{\text { Figure2 }}$}

\section{The Percentages of Stress Placement Correct Responses by Advanced Level Participants}

On the opposite side, the types and percentage of errors done by the participants were analyzed. In table 2 , it is observed that the production of the advanced level participants was better than the production of intermediate level participants. In addition, the table shows that at advanced level, there is progress at the production of the second, third, and fourth rules of MSA stress. The errors increased at first rule. At the intermediate level, the first rule scored fewer errors than the other rules, while it is the opposite at the advanced level. All participants missed applying rule four at the word /'wa:li.da.ti(i)/ "my mother" at the two levels. The percentage of errors was varied and not repetitive with certain rules or words which explains that the errors were not common neither related to definite proficiency level. 
العدق التزاسع عشر / يناير 2022هـ هجلة كلية الآكاهب باهعة بهر(سعيد

\begin{tabular}{|c|c|c|c|c|c|c|c|c|c|c|}
\hline $\begin{array}{c}\text { Advanced- } \\
\text { Level } \\
\text { Participants }\end{array}$ & $\mathrm{A}$ & $\mathrm{B}$ & $\mathrm{C}$ & $\mathrm{D}$ & $\mathrm{E}$ & $\mathrm{F}$ & $\mathrm{G}$ & $\mathrm{H}$ & $\mathrm{I}$ & $\mathrm{J}$ \\
\hline $\mathrm{R} 1$ & $10 \%$ & $3.3 \%$ & 0 & 0 & 0 & $6.6 \%$ & $3.3 \%$ & $6.6 \%$ & 0 & 0 \\
\hline $\mathrm{R} 2$ & 0 & 0 & 0 & 0 & 0 & 0 & 0 & 0 & 0 & 0 \\
\hline $\mathrm{R} 3$ & $3.3 \%$ & 0 & 0 & 0 & 0 & 0 & 0 & 0 & 0 & 0 \\
\hline R4 & $3.3 \%$ & $3.3 \%$ & $3.3 \%$ & $3.3 \%$ & $3.3 \%$ & $3.3 \%$ & $3.3 \%$ & $3.3 \%$ & $3.3 \%$ & $3.3 \%$ \\
\hline $\begin{array}{c}\text { Intermediate- } \\
\text { Level }\end{array}$ & $\mathrm{K}$ & $\mathrm{L}$ & $\mathrm{M}$ & $\mathrm{N}$ & $\mathrm{O}$ & $\mathrm{P}$ & $\mathrm{Q}$ & $\mathrm{R}$ & $\mathrm{S}$ & $\mathrm{T}$ \\
\hline Participants & 0 & $3.3 \%$ & $3.3 \%$ & 0 & 0 & 0 & 0 & 0 & 0 & 0 \\
\hline $\mathrm{R} 1$ & 0 & $6.6 \%$ & 0 & 0 & 0 & 0 & $10 \%$ & 0 & 0 & 0 \\
\hline $\mathrm{R} 2$ & 0 & $6.6 \%$ & 0 & 0 & 0 & 0 & $26.6 \%$ & 0 & 0 & 0 \\
\hline $\mathrm{R} 3$ & $3.3 \%$ & $6.6 \%$ & $3.3 \%$ & $3.3 \%$ & $3.3 \%$ & $3.3 \%$ & $6.6 \%$ & $3.3 \%$ & $3.3 \%$ & $3.3 \%$ \\
\hline $\mathrm{R} 4$ & & & & & & & & & & \\
\hline
\end{tabular}

\section{Table 2}

The Percentage of the Participants' Productions Errors of the MSA Stress Rules.

Meanwhile, the results show that there are different patterns of producing L2 MSA Arabic stress by L1 Chinese speakers as follows:

- Correct pronunciation of the target word with correct syllabic structure and accurate stress placement.

- Correct phoneme pronunciation of the target word with incorrect syllabic structure and inaccurate stress placement.

- /Sa.ra.'biy.ya/ $\rightarrow$ /'Sar.biy.ya/

/CV.CV. 'CVC.CV/ $\rightarrow$ /CVC.CVC.CV/

- Correct phoneme pronunciation of the target word with incorrect syllabic structure and accurate stress placement. 
- / 0al.'la:3a / $\rightarrow$ / 0a.'Ia:3a/

/CVC.CVV.CV/ $\rightarrow$ /CV.CVC.CV/

Different types of phonological error processes are observed in the speech of the participants with different percentages of frequency of occurrences.

1. "Final Consonant Deletion" in which a final consonant was deleted in a super-heavy syllable. This is the most frequent phonological process at the advanced level (14 times), as in the word /șa'ba:h/ "morning" that was pronounced as /șa.'ba:/, but they kept the correct stress placement. Also, a final consonant was deleted from its heavy syllable twice in the word /mu(u).wað..ðaf/ "employee" that was pronounced /mu(u).wad. . $\underline{\text { da }} /$.

2. "Vowel Deletion" in which a vowel in the second syllable was deleted, as in / a.ra.'biy.ya / "a car" was pronounced as /'Sar.biy.ya/. This process happened mostly at the intermediate level.

3. "Shortening of Long Vowel" in which a vowel was shortened in a super-heavy syllable, as in /mu.tar.3i.'mu:n/ "translators" was pronounced as /mu.tar.Ji.'mun/. Participants placed stress correctly according to the new pronunciation at advanced level. At the intermediate level, a participant placed stress correctly and another located it wrongly according to the new pronunciation.

4. "Gemination Deletion" in which one of the geminated phonemes was deleted, as in /0al.'la:.3a/ "fridge" that was pronounced as

$/ \theta a(a)$. 'la:.3a /. This process happened mostly at the intermediate level. Participants of the two levels placed stress correctly according to the pronunciation. 
5. "Vowel Epenthesis" in which a short vowel was inserted between two consonants, the first in a syllable coda and the second is in an initial syllable, as in /'warda/ "rose" was pronounced /'wa.ri.da/. This process happened mostly at intermediate level. Participants at the two levels placed stress correctly according to the pronunciation.

6. "Cluster Reduction" in which one member of the cluster is deleted as in /Pib.ti.da:.Piyy/ "primary" that is pronounced as /Pib.ti.da:.2i:/ or /Pib.ti.da:.Pi/, with an accurate stress placement. Participants had no difficulty in placing the stress to the right position in this word either it was pronounced /Pib.ti.da:.?iyy/, or /Pib.ti.da:.?i:/.

Coming to the transfer of L1 Chinese into L2 MSA, it appears when the participants across the two levels were stressing the final nonsuper heavy syllable at disyllabic and tri-syllabic targets. This process of stressing non stressed final syllables resembles the prominence of final syllable in Chinese disyllabic words as noted by Duanmu, S. (2007).

To sum up, the results of this study prove that participants acquiring the MSA word stress in an accurate way. 


\section{Conclusions}

It is well obvious that the participants' mispronunciation did not lead to the wrong placement of stress. Stress placement may be shifted because of certain types of phonological errors that occur in the speech of the participants. These errors are mostly related to difficulty in producing Arabic word syllabic structure. For example, when the number of the syllabic structure decreases by phonological processes as "vowel deletion", this may due to the elimination of the syllable that carries stress, in this instance the stress must be shifted to another syllable.

When the Chinese learners of Arabic have errors at the segmental level such as the substitution of $/ \mathrm{r} /$ by $/ \mathrm{l} /, / \mathrm{h} /$ by $/ \mathrm{R} /$, and $/ \mathrm{c} / \mathrm{by} / \mathrm{R} /$, these types of errors influenced the intelligibility of their speech in a very negative way. In the current study, when the participants of the intermediate and advanced levels produce stress placement in wrong place, this does not affect the intelligibility of their speech and can't be regarded as an obstacle for communication, unlike the wrong production of Arabic phonemes.

When Chinese learners of Arabic master the Arabic syllabic structure of words (number, type) the stress patterns will be mastered as a sequence. 


\section{Appendix I}

\section{Stress Word Test}

\begin{tabular}{|c|c|c|c|c|c|}
\hline \multirow{2}{*}{$\begin{array}{c}\text { Target } \\
\text { words of } \\
\text { Rule } 1\end{array}$} & \multirow{2}{*}{$\begin{array}{l}\text { Target words } \\
\text { Transcription \& } \\
\text { Syllabifications }\end{array}$} & \multirow{2}{*}{$\begin{array}{c}\text { Participants' } \\
\text { Transcribed } \\
\text { words' } \\
\text { Responses \& } \\
\text { Syllabifications }\end{array}$} & \multicolumn{2}{|c|}{$\begin{array}{c}\text { Participants' } \\
\text { Responses }\end{array}$} & \multirow{2}{*}{$\begin{array}{l}\text { Phonological } \\
\text { Processes } \\
\text { Error } \\
\text { patterns \& } \\
\text { Notes }\end{array}$} \\
\hline & & & Correct & $\begin{array}{c}\text { In- } \\
\text { Correct }\end{array}$ & \\
\hline "سريز & $\begin{array}{l}\text { /sa.ri:r/ } \\
\text { CV.'CV:C }\end{array}$ & & & & \\
\hline $\begin{array}{l}\text { كتاب" } \\
\text { "book" }\end{array}$ & $\begin{array}{c}\text { /ki.ta:b/ } \\
\text { CV.'CV:C }\end{array}$ & & & & \\
\hline "morning" & $\begin{array}{l}\text { /șa.ba:‡/ } \\
\text { CV.'CV:C }\end{array}$ & & & & \\
\hline $\begin{array}{c}\text { أستناذ } \\
\text { "teacher" }\end{array}$ & $\begin{array}{c}\text { /Pus.ta: }: / \\
\text { CVC.'CV:C }\end{array}$ & & & & \\
\hline $\begin{array}{c}\text { أفراد" } \\
\text { "individuals" }\end{array}$ & $\begin{array}{l}\text { /Paf.ra:d/ } \\
\text { CVC.'CV:C }\end{array}$ & & & & \\
\hline $\begin{array}{l}\text { حلويات" } \\
\text { "candy" }\end{array}$ & $\begin{array}{c}\text { /hul.wiy.ya:t/ } \\
\text { CV.CV.CVC.'CV:C } \\
\text { //hul.wi(i).ya:t/ } \\
\text { CVC.CV(V).'CV:C }\end{array}$ & & & & \\
\hline $\begin{array}{l}\text { "translators" } \\
\text { "trang }\end{array}$ & $\begin{array}{l}\text { /mu.tar.3i.mu:n/ } \\
\text { CV.CVC.CV.'CV:C } \\
\text {,/mu.tar.gi.mu:n/ } \\
\text { CV.CVC.CV.'CV:C }\end{array}$ & & & & \\
\hline $\begin{array}{c}\text { تلفزيون" } \\
\text { "television" }\end{array}$ & $\begin{array}{c}\text { /ti.li:.fiz.yu:n/ } \\
\text { CV.CV:.CVC.'CV:C }\end{array}$ & & & & \\
\hline $\begin{array}{c}\text { ابتدائيّ } \\
\text { "primary" }\end{array}$ & $\begin{array}{c}\text { /Pib.ti.da:.'Piyy/ } \\
\text { CVC.CV.'CV:.'CVCC }\end{array}$ & & & & \\
\hline $\begin{array}{c}\text { Target } \\
\text { Words of } \\
\text { Rule } 2\end{array}$ & $\begin{array}{l}\text { Target words } \\
\text { Transcription }\end{array}$ & & & & \\
\hline $\begin{array}{c}\text {-ensineer" } \\
\text { "engineer }\end{array}$ & $\begin{array}{l}\text { /mu.han.dis/ } \\
\text { CV.'CVC.CVC }\end{array}$ & & & & \\
\hline $\begin{array}{c}\text { مترجم" } \\
\text { "translator" }\end{array}$ & $\begin{array}{l}\text { /mu.tar.3im/, /mu.tar.gim/ } \\
\text { CV.'CVC.CVC }\end{array}$ & & & & \\
\hline 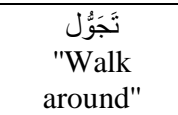 & $\begin{array}{c}\text { /taZaw.wul/, /ta.gaw.wul/ } \\
\text { CV.'CVC.CVC }\end{array}$ & & & & \\
\hline
\end{tabular}


The Acquisition of L2 Modern Standard Arabic... Dr. Mona Maamoun

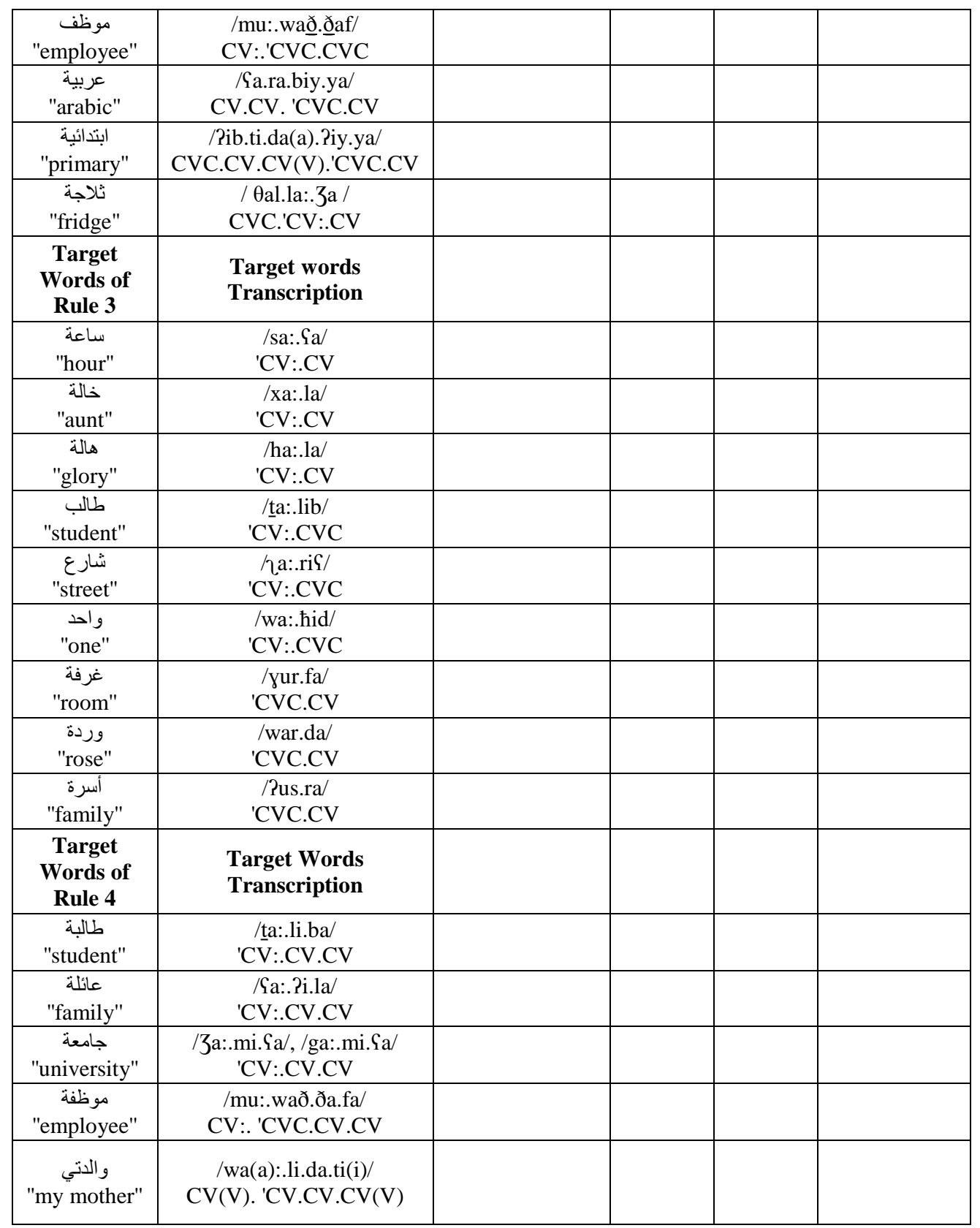




\section{Appendix II}

\section{A Sample Result of the Stress Test of an Intermediate Level Chinese Participant}

\begin{tabular}{|c|c|c|c|c|c|}
\hline \multirow{2}{*}{$\begin{array}{c}\text { Target } \\
\text { words of } \\
\text { Rule } 1\end{array}$} & \multirow{2}{*}{$\begin{array}{c}\text { Target words } \\
\text { Transcription \& } \\
\text { Syllabifications }\end{array}$} & \multirow{2}{*}{$\begin{array}{c}\text { Participants' } \\
\text { Transcribed } \\
\text { Words' } \\
\text { Responses \& } \\
\text { Syllabifications }\end{array}$} & \multicolumn{2}{|c|}{$\begin{array}{l}\text { Participants' } \\
\text { Responses }\end{array}$} & \multirow[t]{2}{*}{$\begin{array}{l}\text { Phonological } \\
\text { Processes } \\
\text { Error } \\
\text { Patterns \& } \\
\text { Notes } \\
\end{array}$} \\
\hline & & & Correct & $\begin{array}{c}\text { In- } \\
\text { Correct }\end{array}$ & \\
\hline سرير "bed" & $\begin{array}{c}\text { /sa.ri:r/ } \\
\text { CV.'CV:C }\end{array}$ & /sa.'ri:r/ & $\sqrt{ }$ & & \\
\hline $\begin{array}{c}\text { كتاب" } \\
\text { "book" }\end{array}$ & $\begin{array}{c}\text { /ki.ta:b/ } \\
\text { CV.'CV:C }\end{array}$ & /ki.'ta:b/ & $\sqrt{ }$ & & \\
\hline $\begin{array}{c}\text { صباح } \\
\text { "morning" }\end{array}$ & $\begin{array}{l}\text { /șa.ba:h/ } \\
\text { CV.'CV:C }\end{array}$ & /șa.'ba:‡/ & $\sqrt{ }$ & & \\
\hline $\begin{array}{c}\text { أستاذ } \\
\text { "teacher" }\end{array}$ & $\begin{array}{c}\text { /Pus.ta:ð/ } \\
\text { CVC.'CV:C }\end{array}$ & /Pus.'ta:ð/ & $\sqrt{ }$ & & \\
\hline $\begin{array}{c}\text { أفر اد } \\
\text { "individuals } \\
\text { " }\end{array}$ & $\begin{array}{l}\text { /Raf.ra:d/ } \\
\text { CVC.'CV:C }\end{array}$ & /Raf.'ra:d/ & $\sqrt{ }$ & & \\
\hline ساعات & $\begin{array}{l}\text { /sa:.'Sa:t./ } \\
\text { CV. 'CVVC }\end{array}$ & /sa:.'Sa:t./ & $\sqrt{ }$ & & \\
\hline $\begin{array}{c}\text { مترجمون } \\
\text { "translators' }\end{array}$ & $\begin{array}{l}\text { /mu.tar.3i. 'mu:n/ } \\
\text { CV.CVC.CV.'CV:C } \\
\text { /mu.tar.gi.mu:n/ } \\
\text { CV.CVC.CV.'CV:C }\end{array}$ & /mu.'tar.3i.mu:n/ & & $\sqrt{ }$ & $\begin{array}{c}\text { Same syllabic } \\
\text { structure } \\
\text { Different } \\
\text { stress } \\
\text { placement }\end{array}$ \\
\hline $\begin{array}{c}\text { تلفزيون } \\
\text { "television" }\end{array}$ & $\begin{array}{c}\text { /ti.li:.fiz.yu:n/ } \\
\text { CV.CV:.CVC.'CV:C }\end{array}$ & /ti.li:.fiz.'yu:n/ & $\sqrt{ }$ & & \\
\hline $\begin{array}{c}\text { Target } \\
\text { words of } \\
\text { Rule } 2\end{array}$ & $\begin{array}{l}\text { Target words } \\
\text { transcription }\end{array}$ & & & & \\
\hline $\begin{array}{c}\text { مـند" } \\
\text { "engineer" }\end{array}$ & $\begin{array}{c}\text { /mu.han.dis/ } \\
\text { CV.'CVC.CVC }\end{array}$ & $\begin{array}{l}\text { /mu.han.'dis/ } \\
\text { CV.CVC.'CVC }\end{array}$ & & $\sqrt{ }$ & \\
\hline $\begin{array}{c}\text { مترجم } \\
\text { "translator" }\end{array}$ & $\begin{array}{l}\text { /mu.tar.3im/, } \\
\text { /mu.tar.gim/ } \\
\text { CV.'CVC.CVC }\end{array}$ & /mu.'tar.3im/ & $\sqrt{ }$ & & \\
\hline $\begin{array}{c}\text { تَجَوُّلُ } \\
\text { "Walk } \\
\text { around" }\end{array}$ & $\begin{array}{c}\text { /taßaw.wul/, } \\
\text { /ta.gaw.wul/ } \\
\text { CV.'CVC.CVC }\end{array}$ & /ta'Zaw.wul/ & $\sqrt{ }$ & & \\
\hline موظف & $\begin{array}{c}\text { /mu:.wad..ðaf/ } \\
\text { CV:.'CVC.CVC }\end{array}$ & /mu:.'wa‥ðaf/ & $\sqrt{ }$ & & \\
\hline
\end{tabular}


The Acquisition of L2 Modern Standard Arabic... Dr. Mona Maamoun

\begin{tabular}{|c|c|c|c|c|c|}
\hline $\begin{array}{c}\text { عربية } \\
\text { "arabic" }\end{array}$ & $\begin{array}{l}\text { /Ga.ra.biy.ya/ } \\
\text { CV.CV. 'CVC.CV }\end{array}$ & $\begin{array}{l}\text { /Sar.'biy.ya/ } \\
\text { CVC.'CVC.CV }\end{array}$ & & $\sqrt{ }$ & $\begin{array}{c}\text { Vowel } \\
\text { Deletion- } \\
\text { Different } \\
\text { syllabic } \\
\text { structure- } \\
\text { Different } \\
\text { stress } \\
\text { placement }\end{array}$ \\
\hline $\begin{array}{c}\text { ابتدائية } \\
\text { "primary" }\end{array}$ & $\begin{array}{c}\text { /Pib.ti.da(a).Piy.ya/ } \\
\text { CVC.CV.CV(V).'CV } \\
\text { C.CV }\end{array}$ & /Pib.ti.da(a).'Piy.ya & $\sqrt{ }$ & & \\
\hline $\begin{array}{c}\text { ابتدائيّ } \\
\text { "primary" }\end{array}$ & $\begin{array}{c}\text { /2ib.ti.da:.'Pi:/ } \\
\text { CVC.CV.'CV:.'CVCC }\end{array}$ & /Pib.ti.'da:.Pi:/ & $\sqrt{ }$ & & \\
\hline $\begin{array}{c}\text { ثلاجة" } \\
\text { "fridge" }\end{array}$ & $\begin{array}{l}\text { / Өal.la:.3a / } \\
\text { CVC.'CV:.CV }\end{array}$ & / Өa. 'la:. 3a / & $\sqrt{ }$ & & $\begin{array}{c}\text { Germination } \\
\text { deletion- } \\
\text { Different } \\
\text { syllabic } \\
\text { structure - } \\
\text { Same stress } \\
\text { placement }\end{array}$ \\
\hline $\begin{array}{c}\text { Target } \\
\text { Words of } \\
\text { Rule } 3\end{array}$ & $\begin{array}{l}\text { Target Words } \\
\text { Transcription }\end{array}$ & & & & \\
\hline $\begin{array}{l}\text { ساعة } \\
\text { "hour" }\end{array}$ & $\begin{array}{l}\text { /sa:.Sa/ } \\
\text { 'CV:.CV }\end{array}$ & /sa:.' $\mathrm{Ya} /$ & & $\sqrt{ }$ & \\
\hline خالة & $\begin{array}{l}\text { /xa:.la/ } \\
\text { 'CV:.CV }\end{array}$ & /xa:.'la/ & & $\sqrt{ }$ & \\
\hline $\begin{array}{c}\text { هالة } \\
\text { "glory" }\end{array}$ & $\begin{array}{l}\text { /ha:.la/ } \\
\text { 'CV:.CV }\end{array}$ & /'ha:.la/ & $\sqrt{ }$ & & \\
\hline "student" & $\begin{array}{l}\text { /ta::lib/ } \\
\text { 'CV:..CVC }\end{array}$ & /'taa:lib/ & $\sqrt{ }$ & & \\
\hline $\begin{array}{c}\text { شارع" } \\
\text { "street" }\end{array}$ & $\begin{array}{l}\text { / } \mathrm{fa}: . \mathrm{riq} / \\
\mathrm{CV}: . \mathrm{CVC}\end{array}$ & l'fa:.ris/ & $\sqrt{ }$ & & \\
\hline $\begin{array}{l}\text { واحد" } \\
\text { "one" }\end{array}$ & $\begin{array}{l}\text { /wa:.hid/ } \\
\text { 'CV:.CVC }\end{array}$ & /'wa:.hid/ & $\sqrt{ }$ & & \\
\hline "room" & $\begin{array}{l}\text { /yur.fa/ } \\
\text { 'CVC.CV }\end{array}$ & /'yur.fa/ & $\sqrt{ }$ & & \\
\hline $\begin{array}{l}\text { وردة" } \\
\text { "rose" }\end{array}$ & $\begin{array}{l}\text { /war.da/ } \\
\text { 'CVC.CV }\end{array}$ & /'war.da/ & $\sqrt{ }$ & & \\
\hline $\begin{array}{c}\text { أسرة" } \\
\text { "family" }\end{array}$ & $\begin{array}{l}\text { /Pus.ra/ } \\
\text { 'CVC.CV }\end{array}$ & /'Pus.su.ra/ & $\sqrt{ }$ & & $\begin{array}{c}\text { Vowel } \\
\text { insertion- } \\
\text { Doubling- } \\
\text { Same stress } \\
\text { placement }\end{array}$ \\
\hline
\end{tabular}




\begin{tabular}{|c|c|c|c|c|c|}
\hline $\begin{array}{c}\text { Target } \\
\text { words of } \\
\text { Rule } 4\end{array}$ & $\begin{array}{l}\text { Target Words } \\
\text { Transcription }\end{array}$ & & & & \\
\hline $\begin{array}{c}\text { طالبة } \\
\text { "student" }\end{array}$ & $\begin{array}{c}\text { /taa:.li.ba/ } \\
\text { 'CV:.CV.CV }\end{array}$ & /'ta:.li.ba/ & $\sqrt{ }$ & & \\
\hline $\begin{array}{c}\text { عائلة } \\
\text { "family" }\end{array}$ & $\begin{array}{l}\text { /दa:.Pi.la/ } \\
\text { 'CV:.CV.CV }\end{array}$ & /'Sa:.Pi.la/ & $\sqrt{ }$ & & \\
\hline $\begin{array}{c}\text { جامعة } \\
\text { "university" }\end{array}$ & $\begin{array}{l}\text { /3a:.mi.Sa/, /ga:.mi.Sa/ } \\
\text { 'CV:.CV.CV }\end{array}$ & /3a:.mi.'Ga/ & & $\sqrt{ }$ & $\begin{array}{c}\text { Same syllabic } \\
\text { structure- } \\
\text { Different } \\
\text { stress } \\
\text { placement }\end{array}$ \\
\hline $\begin{array}{c}\text { موظفة } \\
\text { "employee" }\end{array}$ & $\begin{array}{c}\text { /mu:.wað.ða.fa/ } \\
\text { CV:. 'CVC.CV.CV }\end{array}$ & /mu:.'wað.ða.fa/ & $\sqrt{ }$ & & \\
\hline $\begin{array}{c}\text { و الدتي } \\
\text { "my } \\
\text { mother" }\end{array}$ & $\begin{array}{c}\text { /wa(a):.li.da.ti(i)/ } \\
\text { CV(V). } \\
\text { 'CV.CV.CV(V) }\end{array}$ & /'wa:.li.da.ti(i)/ & $\sqrt{ }$ & & \\
\hline
\end{tabular}




\section{Appendix III}

\section{A Sample Result of the Stress Test of an advanced Level}

\section{Chinese Participant}

\begin{tabular}{|c|c|c|c|c|c|}
\hline \multirow{2}{*}{$\begin{array}{c}\text { Target } \\
\text { words of } \\
\text { Rule } 1\end{array}$} & \multirow{2}{*}{$\begin{array}{l}\text { Target words } \\
\text { Transcription \& } \\
\text { Syllabifications }\end{array}$} & \multirow{2}{*}{$\begin{array}{c}\text { Participants' } \\
\text { Transcribed } \\
\text { Words' } \\
\text { Responses \& } \\
\text { Syllabifications }\end{array}$} & \multicolumn{2}{|c|}{$\begin{array}{c}\text { Participants' } \\
\text { Responses }\end{array}$} & \multirow[t]{2}{*}{$\begin{array}{c}\text { Phonological } \\
\text { Processes } \\
\text { Error } \\
\text { Patterns \& } \\
\text { Notes } \\
\end{array}$} \\
\hline & & & correct & $\begin{array}{c}\text { In- } \\
\text { correct }\end{array}$ & \\
\hline سرير" & $\begin{array}{l}\text { /sa.'ri:r/ } \\
\text { CV.CV:C }\end{array}$ & $\begin{array}{l}\text { /'sa.ri:r/ } \\
\text { 'CV.CVVC }\end{array}$ & & $\sqrt{ }$ & $\begin{array}{c}\text { Same } \\
\text { syllabic } \\
\text { structure- } \\
\text { Different } \\
\text { stress } \\
\text { placement }\end{array}$ \\
\hline $\begin{array}{l}\text { كتاب" } \\
\text { "book" }\end{array}$ & $\begin{array}{l}\text { /ki.'ta:b/ } \\
\text { CV.CV:C }\end{array}$ & /ki.'ta:b/ & $\sqrt{ }$ & & \\
\hline $\begin{array}{c}\text { صباح } \\
\text { "morning" }\end{array}$ & $\begin{array}{l}\text { /șa.'ba:ћ/ } \\
\text { CV.CV:C }\end{array}$ & /ṣa.'ba:/ & $\sqrt{ }$ & & \\
\hline $\begin{array}{c}\text { أستاذ } \\
\text { "teacher" }\end{array}$ & $\begin{array}{l}\text { /Pus.'ta:ð/ } \\
\text { CVC.CV:C }\end{array}$ & /Pus.'ta:/ & $\sqrt{ }$ & & \\
\hline $\begin{array}{c}\text { أفراد } \\
\text { "individuals } \\
\text { " }\end{array}$ & $\begin{array}{l}\text { /Paf.'ra:d/ } \\
\text { CVC.CV:C }\end{array}$ & /Paf.'ra:d/ & $\sqrt{ }$ & & \\
\hline ساعات & $\begin{array}{l}\text { /sa:.'Ya:t./ } \\
\text { CV:.CV:C }\end{array}$ & /sa:.'Ya:t./ & $\sqrt{ }$ & & \\
\hline $\begin{array}{c}\text { مترجمون } \\
\text { "translators' }\end{array}$ & $\begin{array}{l}\text { /mu.tar.3i.'mu:n/, } \\
\text { /mu.tar.gi.'mu:n/ } \\
\text { CV.CVC.CV.CV:C }\end{array}$ & /mu.tar.Zi.'mu:n/ & $\sqrt{ }$ & & \\
\hline $\begin{array}{c}\text { تلفزيون" } \\
\text { "television" }\end{array}$ & $\begin{array}{l}\text { /ti.li:.fiz.'yu:n/ } \\
\text { CV.CV.CVC.CV:C }\end{array}$ & $\begin{array}{l}\text { /til.fiz.'yu:n/ } \\
\text { CVC.CVC.CV:C }\end{array}$ & $\sqrt{ }$ & & \\
\hline
\end{tabular}




\begin{tabular}{|c|c|c|c|c|c|}
\hline $\begin{array}{c}\text { Target } \\
\text { words of } \\
\text { Rule } 2\end{array}$ & $\begin{array}{l}\text { Target words } \\
\text { transcription }\end{array}$ & $\begin{array}{c}\text { Subject } \\
\text { Transcription }\end{array}$ & & & \\
\hline $\begin{array}{c}\text { من مند" } \\
\text { "engineer" }\end{array}$ & $\begin{array}{l}\text { /mu.'han.dis/ } \\
\text { CV.CVC.CVC }\end{array}$ & /mu.'han.dis/ & $\sqrt{ }$ & & \\
\hline $\begin{array}{c}\text { مترجم" } \\
\text { "translator" }\end{array}$ & $\begin{array}{l}\text { /mu.'tar.3im/, } \\
\text { /mu.'tar.gim/ } \\
\text { CV.CVC.CVC }\end{array}$ & /mu.'tar.3im/, & $\sqrt{ }$ & & \\
\hline $\begin{array}{c}\text { تَجَوُّل } \\
\text { "Walk } \\
\text { around" }\end{array}$ & $\begin{array}{l}\text { /ta'Zaw.wul/, } \\
\text { /ta.'gaw.wul/ } \\
\text { CV.CVC.CVC }\end{array}$ & $\begin{array}{l}\text { /ta.'3a:.wul/ } \\
\text { CV. 'CVV.CVC }\end{array}$ & & $\sqrt{ }$ & $\begin{array}{c}\text { Germination } \\
\text { deletion }+ \\
\text { Vowel } \\
\text { lengthening- } \\
\text { Different } \\
\text { syllabic } \\
\text { structure- } \\
\text { Same stress } \\
\text { placement }\end{array}$ \\
\hline "employee" & $\begin{array}{l}\text { /mu:.'wa } \underline{\text { dogaf/ }} \\
\text { CV:.CVC.CVC }\end{array}$ & /mu:.'wadِ.ㅁaf/ & $\sqrt{ }$ & & \\
\hline $\begin{array}{c}\text { عربية" } \\
\text { "arabic" }\end{array}$ & $\begin{array}{l}\text { /Ya.ra.'biy.ya/ } \\
\text { CV.CV.CVC.CV }\end{array}$ & /Sa.ra.'biy.ya/ & $\sqrt{ }$ & & \\
\hline $\begin{array}{c}\text { ابتدائية } \\
\text { "primary" }\end{array}$ & $\begin{array}{l}\text { /Pib.ti.da(a).'Piy.ya/ } \\
\text { CVC.CV.CV(V).CVC } \\
\text {.CV }\end{array}$ & /Rib.ti.da(a).'Piy.ya & $\sqrt{ }$ & & \\
\hline $\begin{array}{l}\text { ابتدائي } \\
\text { "pri } \\
\text { mary" }\end{array}$ & $\begin{array}{c}\text { /Pib.ti.da:.'Piyy/ } \\
\text { /Pib.ti.'da:.?i:/ } \\
\text { /Pib.ti.'da:.?i/ } \\
\text { CVC.CV.CV..CVCC }\end{array}$ & /Pib.ti.da:.'Piyy/ & $\sqrt{ }$ & & \\
\hline $\begin{array}{c}\text { ثلاجة" } \\
\text { "fridge" }\end{array}$ & / өal.'la:.3a / & / Өal.'1a:.3a / & $\sqrt{ }$ & & \\
\hline $\begin{array}{c}\text { Target } \\
\text { words of } \\
\text { Rule } 3\end{array}$ & $\begin{array}{l}\text { Target words } \\
\text { transcription }\end{array}$ & $\begin{array}{c}\text { Subject } \\
\text { Transcription }\end{array}$ & & & \\
\hline " ساعة & $\begin{array}{l}\text { /sa:.Sa/ } \\
\text { CV:.CV }\end{array}$ & /'sa:.Sa/ & $\sqrt{ }$ & & \\
\hline $\begin{array}{c}\text { خالة } \\
\text { "aunt" }\end{array}$ & $\begin{array}{l}\text { /xa:.la/ } \\
\text { CV:.CV }\end{array}$ & /'xa:.la/ & $\sqrt{ }$ & & \\
\hline $\begin{array}{l}\text { هالة" } \\
\text { "glory" }\end{array}$ & $\begin{array}{l}\text { /'ha:.la/ } \\
\text { CV:.CV }\end{array}$ & /'ha:.la/ & $\sqrt{ }$ & & \\
\hline
\end{tabular}


The Acquisition of L2 Modern Standard Arabic... Dr. Mona Maamoun

\begin{tabular}{|c|c|c|c|c|c|}
\hline طالب & $\begin{array}{l}\text { /'ta:.lib/ } \\
\text { CV:.CVC }\end{array}$ & /'ta:.lib/ & $\sqrt{ }$ & & \\
\hline شارع" & $\begin{array}{l}\text { /'aa:.ris/ } \\
\text { CV:.CVC }\end{array}$ & /'za:ris/ & $\sqrt{ }$ & & \\
\hline $\begin{array}{l}\text { واحد" } \\
\text { "one" }\end{array}$ & $\begin{array}{l}\text { /'wa:.hid/ } \\
\text { CV:.CVC }\end{array}$ & /'wa:.hid/ & $\sqrt{ }$ & & \\
\hline $\begin{array}{c}\text { غرفة } \\
\text { "room" }\end{array}$ & $\begin{array}{l}\text { /'yur.fa/ } \\
\text { CVC.CV }\end{array}$ & /'yur.fa/ & $\sqrt{ }$ & & \\
\hline $\begin{array}{l}\text { وردة } \\
\text { "rose" }\end{array}$ & $\begin{array}{l}\text { /'war.da/ } \\
\text { CVC.CV }\end{array}$ & /'war.da/ & $\sqrt{ }$ & & \\
\hline أسرة & $\begin{array}{l}\text { /'Pus.ra/ } \\
\text { CVC.CV }\end{array}$ & $\begin{array}{l}\text { /Pus.'ra/ } \\
\text { CVC. 'CV }\end{array}$ & $\sqrt{ }$ & & \\
\hline $\begin{array}{c}\text { Target } \\
\text { words of } \\
\text { Rule } 4\end{array}$ & $\begin{array}{l}\text { Target words } \\
\text { transcription }\end{array}$ & $\begin{array}{c}\text { Subject } \\
\text { Transcription }\end{array}$ & & & \\
\hline $\begin{array}{c}\text { طالبة } \\
\text { "student" }\end{array}$ & $\begin{array}{l}\text { /'ta:.li.ba/ } \\
\text { CV:.CV.CV }\end{array}$ & /'taa:.li.ba/ & $\sqrt{ }$ & & \\
\hline $\begin{array}{c}\text { عائلة } \\
\text { "family" }\end{array}$ & $\begin{array}{l}\text { /'Ga:.Pi.la/ } \\
\text { CV:.CV.CV }\end{array}$ & /'Ga:.Pi.la/ & $\sqrt{ }$ & & \\
\hline $\begin{array}{c}\text { جامعة } \\
\text { "university" }\end{array}$ & $\begin{array}{l}\text { /'Za:.mi.Sa/, } \\
\text { /'ga:.mi.Sa/ } \\
\text { CV:.CV.CV }\end{array}$ & /'Za:.mi.9a/ & $\sqrt{ }$ & & \\
\hline $\begin{array}{c}\text { موظفة" } \\
\text { "employee" }\end{array}$ & $\begin{array}{c}\text { /mu..'wað.ða.fa/ } \\
\text { CV(V).CVC.CV.CV }\end{array}$ & /mu:.'wað.ða.fa/ & $\sqrt{ }$ & & \\
\hline $\begin{array}{c}\text { والدتي } \\
\text { "my } \\
\text { mother" }\end{array}$ & $\begin{array}{c}\text { /wa(a):.'li.da.ti(i)/ } \\
\text { CV(V).CV.CV.CV(V) }\end{array}$ & $\begin{array}{l}\text { /'wa:.li.da.ti(i)/ } \\
\text { 'CVV.CV.CV.CV }\end{array}$ & & $\sqrt{ }$ & $\begin{array}{c}\text { different } \\
\text { syllabic } \\
\text { structure- } \\
\text { different } \\
\text { stress } \\
\text { placement }\end{array}$ \\
\hline
\end{tabular}




\section{REFRENCES}

${ }^{1} \mathrm{https}$ ://www.thenationalnews.com/world/asia/arabic-is-now-amust-learn-language-in-china-1.682090

${ }^{2}$ Roach, P. (1991). English Phonetics and Phonology. Cambridge: Cambridge University Press.

3 Liu, D. (2017). The Acquisition of English Word Stress by Mandarin EFL Learners. English Language Teaching, 10(12), 196-201.

${ }^{4}$ Chakraborty, R. \& Goffman, L. (2010). Production of Lexical Stress in Non-Native Speakers of American English: Kinematic Correlates of Stress and Transfer. Journal of Speech Language and Hearing Research, 54(3), 821. doi:10.1044/1092-4388(2010/09-0018).

5 Al-Jarrah, R. (2002). An optimality-theoretic analysis of stress in the English of native Arabic speakers. Thesis ( $\mathrm{PhD})$. Ball State University.

${ }^{6}$ Fry (1958). Experiments in the Perception of Stress. University College. London. https://doi.org/10.1177\%2F0023830958001 $\underline{00207}$

${ }^{7} \mathrm{Ou}$, S., \& Ota, M. (2015). Is second-language stress acquisition guided by metrical principles? Evidence from mandarinspeaking learners of English. doi:10.13140/2.1.4443.0408

${ }^{8}$ Altmann, H. (2006). The perception and production of second language stress: A cross-linguistic experimental study.

Newark, DE, USA: University of Delaware.

9 Liu, D. (2017). The Acquisition of English Word Stress by Mandarin EFL Learners. English Language Teaching, 10(12), 196-201.

10 Özçelik, Ö. (2016). Acquisition of FOREIGN LANGUAGE Turkish prosody the effects of purely phonological and phonosyntactic issues. In Second Language Acquisition of Turkish (pp. 20-48). Amsterdam: John Benjamins. 
11 Selinker, L. (1972). Interlanguage. International Review of Applied Linguistics, 10 (3), 209-241.

${ }^{12}$ Eckman, F., 2008. Typological markedness and L2 phonology. In: J. Edwards and M. Zampini, eds. Phonology and second language acquisition. Philadelphia: John Benjamins, (P. 95115).

13 Hancin-Bhatt, B., (2008). Second language phonology in optimality theory. In: J. Edwards and M. Zampini,eds. Phonology and second language acquisition. Philadelphia: John Benjamins, 117-146

14 Yang, C. (2011). The acquisition of Mandarin prosody by American learners of Chinese as a foreign language (CFL) (Unpublished doctoral dissertation).

${ }^{15} \mathrm{He}$, X., Heuven, V., \& Gussenhoven, C. (2012). The selection of intonation contours by Chinese FOREIGN LANGUAGE speakers of Dutch: Orthographic closure vs. prosodic knowledge. Second Language Research, 28(3), 283-318.

16 Johnson, S. and Newport, E. (1989). Critical period effects in second language learning: The influence of maturational state on the acquisition of English as a second language. Journal of Cognitive Psychology, 21, 60-99.

17 Morley, J. (1991). The pronunciation component in teaching English to speakers of other languages. TESOL Quarterly, 25 (3), (p.481-520).

18 Pan, Q. (2012). The Comparative Study on English and Chinese Intonation. doi:10.4304/tpls.2.1.161-164

20 Al-Aloula. M. (2018). Production of Modern Standard Arabic lexical stress cues by native speakers of American English from: The Routledge handbook of Arabic second language acquisition. Milton Park, Abingdon, Oxon: New York, NY. https://www.routledgehandbooks.com/doi/10.4324/97813156 74261-3 
${ }^{21}$ Betti,M., \& Ulaiwi,W. (2018). Stress in English and Arabic: A contrastive study. English Language and Literature Studies,8(1), 83. doi:10.5539/ells. v8 (1) (p83).

22 Holes, C. (2004). Modern Arabic structures, functions, and varieties. Washington, D.C.: Georgetown University Press. 163.

23 Halpern, J. (2009, February). Word Stress and Vowel Neutralization in Modern Standard Arabic. Tohoku, Niizashi, Saitama 352-0001, Japan. Retrieved December 24, 2018, from http://www.elda.org/medar-conference/pdf/16.pdf

${ }^{24}$ Ryding, K. C. (2005). A reference grammar of modern standard Arabic. Cambridge: Cambridge Univ. Press. 22-39.

25 Alrajeh, N. (2011). Digital processing of stress in Standard Arabic. Journal of King Saud University - Languages and Translation, 23(2), 65-68. https://doi:10.1016/j.jksult.2011.03.001

26 Watson, J. (2011). "Word Stress in Arabic." In The Blackwell Companion to Phonology, 5, edited by Mark Oostendorp, C. Ewen, E. Hume, and Karen Rice, 2990-3018. Oxford: WileyBlackwell.

27 Alrajeh, N. (2011). Digital processing of stress in Standard Arabic. Journal of King Saud University - Languages and Translation, 23(2), 65-68. https://doi:10.1016/j.jksult.2011.03.001

$29 \mathrm{Xu}, \mathrm{Y}$. (2015). Intonation in Chinese. In (Ed.), The Oxford Handbook of Chinese Linguistics.: Oxford University Press. Retrieved $30 \quad$ Oct. 2018, from http://www.oxfordhandbooks.com/view/10.1093/oxfordhb/97 80199856336.001.0001/oxfordhb-9780199856336-e-12.

30 Huang, C., Li, Y., \& Simpson, A. (2014). The handbook of Chinese linguistics. Hoboken, NJ: John Wiley \& Sons. 
${ }^{31}$ Yastreblyanska, M. (2012). Word Stress in Chinese and Ukrainian Languages: Problems of Typology. Mediterranean Journal of Social Sciences, 3, 4.

${ }^{32}$ Chao, Y. (1965). A grammar of spoken Chinese. Berkeley (Calif.): University of California Press.

${ }^{33}$ Duanmu, S. (2007). The Phonology of Standard Chinese (p: 129157). New York: Oxford University Press.

${ }^{34}$ Archibald, J. (1997). The acquisition of English stress by speakers of nonaccentual languages: Lexical storage versus computation of stress. Linguistics, 35, 167-181. https://doi.org/10.1515/ling.1997.35.1.167

${ }^{35}$ Chao, Y. (1965). A grammar of spoken Chinese. Berkeley (Calif.): University of California Press.

36 Aijun, L. (2002). Chinese Prosody and Prosodic Labeling of Spontaneous Speech. http://isle.illinois.edu/sprosig/sp2002/pdf/aijun.pdf

${ }^{37}$ Chao, Y. (1965). A grammar of spoken Chinese. Berkeley (Calif.): University of California Press.

${ }^{38}$ Brustad, K., Al-Batal, M., \& Al-Tonsi, A. (2007). Al-Kitaab fii Tacallum al-cArabiyya: With DVD and MP3 $C D=A$ textbook for Beginning Arab (3rd ed.). Washington, D.C: Georgetown University Press. 